\title{
Petrography and geochronology of the Nxau Nxau kimberlites, north-west Botswana
}

\author{
Henrietta Farr ${ }^{1}$, David Phillips ${ }^{1}$ and Mike de Wit ${ }^{2,3}$ \\ ${ }^{1}$ KiDs (Kimberlites and Diamonds), School of Earth Sciences, The University of Melbourne, Parkville, 3010, \\ Victoria, Australia \\ ${ }^{2}$ Tsodilo Resources Ltd, Toronto, Ontario, Canada \\ ${ }^{3}$ Delrand Resources Pty Ltd., Toronto, Ontario, Canada
}

\section{Introduction}

The Nxau Nxau kimberlite cluster is part of the Xaudum province on the south-eastern margin of the Congo craton, which straddles the border between Namibia and Botswana. This kimberlite province is geographically isolated from other known kimberlites and occurs in an area previously thought to be part of the Damara mobile belt. The kimberlites were emplaced within the outer limits of the Okavango Mafic Dyke Swarm which was emplaced as part of the early Jurassic Karoo magmatism, although some dykes are Proterozoic in age (Jourdan et al. 2004). Nineteen kimberlites were discovered in 1997 with another 9 discovered in 2005-06 by Tsodilo Resources. Exploration interest in this area gathered momentum after 20\% of garnets analysed by Rio Tinto Namibia Pty Ltd. from 1994 to 1996 exhibited subcalcic G10 compositions (Hoal et al. 2000).

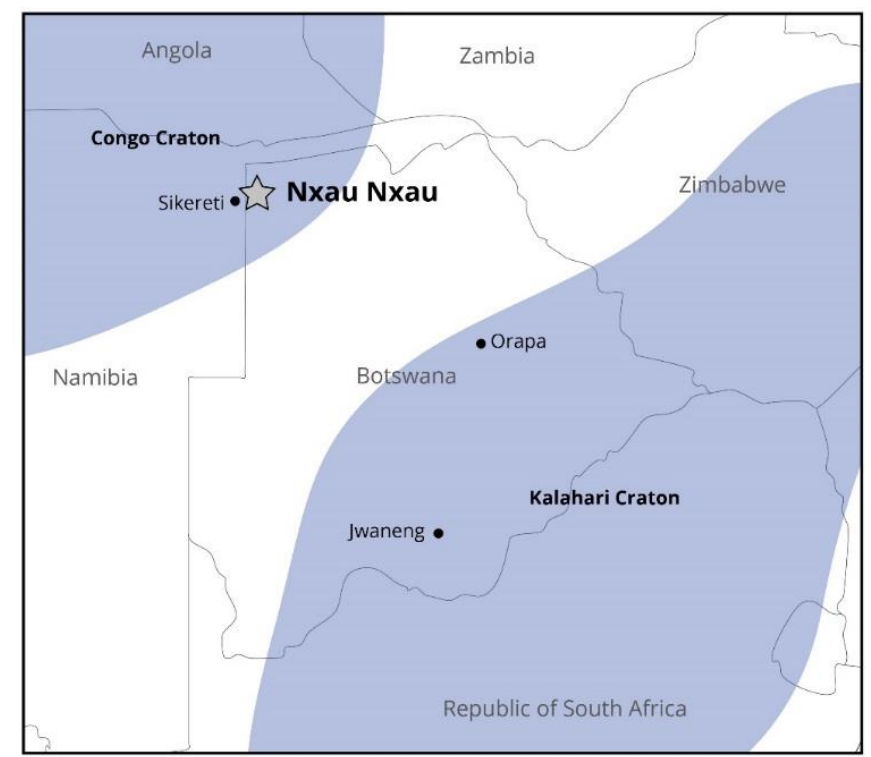

Figure 1: Map showing the location of the Nxau Nxau kimberlite field in relation to the Congo and Kalahari Cratons. The locations of the Sikereti, Orapa and Jwaneng kimberlites are also shown.

\section{Petrography}

A variety of volcaniclastic and hypabyssal units were observed in the Nxau Nxau samples. Samples from kimberlites in close proximity to the dykes are predominantly volcaniclastic and contain a higher proportion of crustal xenoliths. The hypabyssal samples can be broadly described as coherent macrocrystic olivine, calcite kimberlites, with serpentinised and calcitised olivine typically up to $1 \mathrm{~mm}$ in size. Titanomagnetite and perovskite $(<100 \mu \mathrm{m})$ are the dominant groundmass phases with apatite and phlogopite being less common. Phlogopite is most abundant in sample B8/1 but generally uncommon. Later veins of kimberlite cross-cut some of the hypabyssal samples with an earlier generation of kimberlite present in one drillhole (2164A1). 
As evident from cross-cutting relationships and xenoliths present within the kimberlites, the kimberlites intruded rocks of the Karoo Supergroup (late Carboniferous - early Jurassic) (Smith 1984), the Damara Supergroup (late Precambrian) and basement granites and gneisses that have been dated at 2.9-2.5Ga (Batumike et al. 2009). Karoo dolerite and Nosib quartzite are the dominant crustal xenoliths present with lesser amphibolite occurrences.

\section{Geochemistry \& Geochronology}

Five samples from four bodies containing sufficient fresh perovskite were analysed for strontium isotopes using in situ LA-ICPMS methods. Four of the samples analysed define a narrow ${ }^{87} \mathrm{Sr}^{86}{ }^{8} \mathrm{Sr}_{\mathrm{i}}$ range around 0.7036 . The most altered sample $(\mathrm{C} 15 / 3)$ gave a significantly higher ${ }^{87} \mathrm{Sr} /{ }^{86} \mathrm{Sr}_{i}$ value of 0.7042 . These results are consistent with values characteristic of archetypal (Group I) kimberlites (Woodhead et al. 2009). A sixth sample (2164A1) contained extensively altered perovskite which was unable to be analysed.

The same five samples were dated using in-situ U-Pb LA-ICPMS methods, giving a weighted average age of $84 \pm 4 \mathrm{Ma}$. Phlogopite from one kimberlite was also analysed by ${ }^{40} \mathrm{Ar} /{ }^{39} \mathrm{Ar}$ and $\mathrm{Rb}-\mathrm{Sr}$ dating yielding an ${ }^{40} \mathrm{Ar} /{ }^{39} \mathrm{Ar}$ inverse isochron age of $86.5 \pm 8.6 \mathrm{Ma}$ (Fig. 2) and a two-point Rb-Sr age of 87.1 $\pm 3.1 \mathrm{Ma}$. All ages are within error of one another.

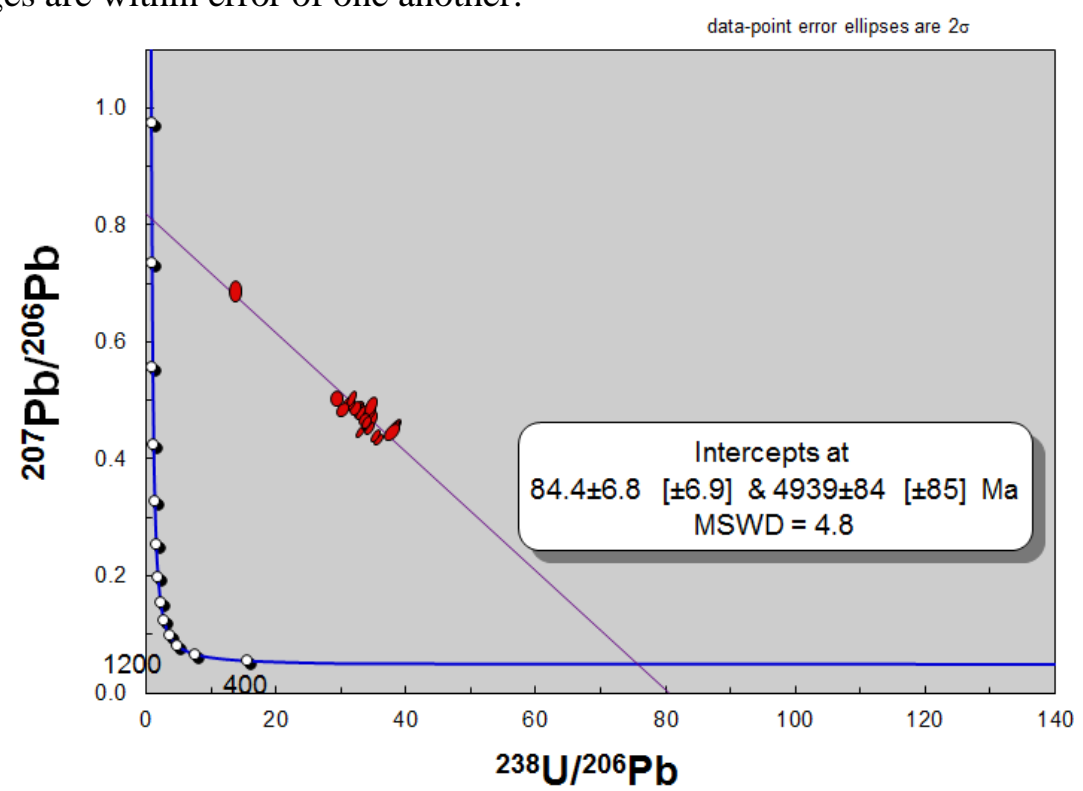

Figure 2: Tera-Wasserburg concordia diagram for sample 21181A4, ellipses show $2 \sigma$

Table 1: Summary of kimberlites ages. U-Pb perovskite ages have been corrected for common lead using the measured abundances of ${ }^{207} \mathrm{~Pb} /{ }^{206} \mathrm{~Pb}$ and ${ }^{238} \mathrm{U} /{ }^{206} \mathrm{~Pb}$ (Tera and Wasserburg 1972). Several other methods of constraining common lead were tested with some giving higher precision; however, the TW intercept proved the most consistent and was deemed the most accurate.

\begin{tabular}{|l|c|c|c|}
\hline Sample & Age $(\mathrm{Ma})$ & Method & Analysis \\
\hline $21181 \mathrm{~A} 4$ & $84.4 \pm 7$ & $\mathrm{U}-\mathrm{Pb}$ perovskite & LA-ICP-MS 23 spots \\
\hline A36/3 & $84.0 \pm 9$ & $\mathrm{U}-\mathrm{Pb}$ perovskite & LA-ICP-MS 24 spots \\
\hline$B 8 / 1$ & $82.5 \pm 1$ & ${ }^{40} \mathrm{Ar} /{ }^{39} \mathrm{Ar}$ phlogopite & $\begin{array}{c}\text { Total gas (3 steps) } \\
\text { from single grain }\end{array}$ \\
\hline & $86.5 \pm 9$ & ${ }^{40} \mathrm{Ar} /{ }^{39} \mathrm{Ar}$ phlogopite & $\begin{array}{c}\text { Inverse isochron (3 } \\
\text { steps) from single } \\
\text { grain }\end{array}$ \\
\hline C15/3 & $87.1 \pm 3$ & Rb-Sr phlogopite & $\begin{array}{c}\text { Two leached } \\
\text { fractions }\end{array}$ \\
\hline $1821 \mathrm{C} 16 / 3$ & $79.0 \pm 6$ & U-Pb perovskite & LA-ICP-MS 20 spots \\
\hline
\end{tabular}




\section{Discussion}

All three dating techniques applied are in agreement that the Nxau Nxau kimberlite field was emplaced at $\sim 84 \mathrm{Ma}$. In this study it is considered that U-Pb perovskite dating gives the most robust and precise results due to extraneous argon and argon loss affecting phlogopite analyses. Therefore, the weighted average of the U-Pb ages ( $84 \pm 4 \mathrm{Ma}$ ) is proposed as the best estimate for the time of emplacement of the Nxau Nxau kimberlites. These kimberlites represent the first known expression of Cretaceous alkaline magmatism in this area and join a large number of other kimberlites emplaced during the Cretaceous from 70-90 Ma. The emplacement of kimberlites in the Cretaceous is considered to be related to the break-up of Gondwana and relevant tectonic stresses. In the case of these kimberlites, a significant reoganisation of global tectonic stresses with the cessation of intra-continental movements within Africa at $84 \mathrm{Ma}$ (Chron 34) may have been a trigger for kimberlite magmatism (Nürnberg and Müller 1991).

The cross-cutting kimberlite (seen in sample 2164A1) was unable to be dated, however, the pervasive alteration suggests that it is significantly older than 84 Ma. Perovskite in this kimberlite is petrographically similar to that of kimberlites in the Kuruman Province, South Africa. From this it is suggested that the older Nxau Nxau kimberlite may fall within the $1000-1200 \mathrm{Ma}$ or $1600-1800 \mathrm{Ma}$ periods of alkaline magmatism.

\section{References}

Batumike JM, Griffin WL, O'Reilly SY, Belousova EA, Pawlitschek M (2009) Crustal evolution in the central Congo-Kasai Craton, Luebo, D.R. Congo: Insights from zircon U-Pb ages, Hf-isotope and trace-element data Precambrian Research 170:107-115 doi:http://dx.doi.org/10.1016/j.precamres.2008.12.001

Hoal K, Hoal B, Griffin W, Armstrong R (2000) Characterization of the age and nature of the lithosphere in the Tsumkwe region, Namibia Communications of the geological survey of Namibia 12:21-28

Jourdan F et al. (2004) The Karoo triple junction questioned: evidence from Jurassic and Proterozoic 40Ar/39Ar ages and geochemistry of the giant Okavango dyke swarm (Botswana) Earth and Planetary Science Letters 222:989-1006 doi:http://dx.doi.org/10.1016/j.epsl.2004.03.017

Nürnberg D, Müller RD (1991) The tectonic evolution of the South Atlantic from Late Jurassic to present Tectonophysics 191:27-53

Smith RA (1984) The lithostratigraphy of the Karoo Supergroup in Botswana. Geological Survey Department with the authority of Ministry of Mineral Resources and Water Affairs, Republic of Botswana,

Tera F, Wasserburg G (1972) U-Th-Pb systematics in three Apollo 14 basalts and the problem of initial $\mathrm{Pb}$ in lunar rocks Earth and Planetary Science Letters 14:281-304

Woodhead J, Hergt J, Phillips D, Paton C (2009) African kimberlites revisited: In situ Sr-isotope analysis of groundmass perovskite Lithos 112S:311-317 